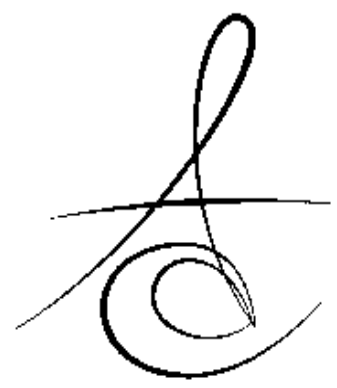

\title{
ÇOCUKLARDA DİŞ ÇÜRÜKLERİ VE RESTORASYONLARIN PERİODONTAL SAĞLIKLA İLIŞKİSİ: BİR LİTERATÜR DERLEMESİ
}

\author{
THE RELATIONSHIP BETWEEN PERIODONTAL HEALTH AND DENTAL \\ CARIES/RESTORATION IN CHILDREN: A REVIEW OF THE LITERATURE
}

\author{
Dr. Öğr. Üyesi Gülsüm DURUK*
}

Prof. Dr. Taşkın GÜRBÜZ**

\author{
Makale Kodu/Article code: 2888 \\ Makale Gönderilme tarihi: 10.06 .2016 \\ Kabul Tarihi: 22.08.2016
}

öz

Periodontal problemler ile ilgili yapılan çalışmalar kuşkusuz çoğunlukla yetişkinleri kapsamaktadır. Çocuklarda karşılaşılan periodontal problemler literatürlerde daha az çalışımıştır. Oysaki süt dişlenme döneminde sıklıkla karşılaşılan kole ve arayüz çürüklerinin, iyi yapılmamış restorasyonların sebep olduğu periodontal harabiyet klinik pratiğinde klinisyenlerin üstesinden gelmek zorunda olduğu bir durumdur. Bu derlemenin amacl; çocuklarda diş çürüğüne veya dental restorasyonlara bağlı oluşan periodontal harabiyet konusunda mevcut bilgileri güncellemek ve daha önce yapılmış çalışmaların ışığı doğrultusunda uygulama yöntemlerini incelemektir.

Anahtar Kelimeler: Ara yüz çürüğü, kole çürüğü, dental restorasyonlar, periodontal parametreler

\section{ABSTRACT}

The studies on periodontal problems are most commonly carried out inadults. Periodontal problems in children have been studied less in literature. Whereas, periodontal destruction that occurs due to cervical and interproximal caries frequently seen in primary dentition and bad dental restorations is a situation in clinical practice that the clinicians have to deal with. The aim of this review is to update the existing information about periodontal destruction that occurs in children due to dental caries or dental restorations and examine the methods of implementation in the light of earlier studies.

Keywords: Interproksimal caries, cervical caries, dental restorations, periodontal parameters

\section{GİRİŞ}

Diş ve diş destek dokuları birbiri ile direk ilişkide olup dişte meydana gelen herhangi bir patolojik durum dişi saran destek dokuları olumsuz etkilemektedir. Gerek diş çürükleri, gerekse anatomik forma sadık kaIınmadan yapılan restorasyonlar diş çevre dokularında istenilmeyen sonuçlara sebep olabilmektedir. ${ }^{1}$

\section{Çürük}

Diş çürükleri, bakteri ve bakteri enzimlerince oluşturulan diş sert dokularının demineralizasyonu ve bunu takiben dokuların yıkımı ile karakterize, çocukluk döneminin en sık karşılaşılan hastalıklarındandır. ${ }^{2,3}$

\section{Çürüğün İlerlemesi}

Bakteri plağının mine yüzeyinde oluşturduğu asit, yüzeyden derine doğru mineyi demineralize ede- rek dokuda yıkıma sebep olmaktadır. Mine-dentin sını rında genişleyen çürük, dentinde daha hızı ilerleyerek, tübüller aracılığıyla pulpaya doğru ilerlemektedir. Alttaki genişlemiş çürükten dolayı, desteksiz kalan minede kırılmalar olmakta ve kavitasyon büyümektedir. Genişlemiş kavitasyonda gıda birikimi sonucunda diş sert dokusu demineralize olup, gevşek bir kıvam almaktadır. ${ }^{3}$ Çürüğün, süt dişlerinde daimi dişlere kıyasla daha hızlı ilerlediği bilinmektedir. Bunun sebebi süt dişi mine tabakasının daimi dişlere kıyasla daha ince olmasıdır. 4 


\section{Ara Yüz Çürüğü}

Süt azı dişleri, geniş ve düz ara yüz değim alanları gibi anatomik özelliklerinden ötürü, süt dişleri içerisinde çürüğe eğilimi en fazla olan dişlerdir. ${ }^{5}$ Murray ve Majid, ${ }^{4}$ süt dişlenmesinde ara yüz çürüklerinin prevelansını ve ilerlemesini araştırdıkları çalışmalarında mine seviyesindeki 71 çürük lezyonundan 69 tanesinin bir yllın sonunda dentine ilerlediğini belirtmişlerdir.

\section{Kole çürüğü}

Dişlerin servikal bölgesinde görülen ve bu bölgenin bir ya da birden fazla yüzeyinde oluşan diş doku kaybıdır. ${ }^{6}$ Dişetinin üstünde, dişeti hizasında ve diş eti altında lokalize olabilirler. Dişeti ile yakın temastadır. Erken çocukluk çağı çürüğünde (EÇÇ) kole çürükleri ile yaygın olarak karşılaşılmaktadır. Çocuklarda kole bölgesi çürüklerinde en sık karşılaşılan sorunlar; bu bölgelerde kavitasyona bağlı gıda retansiyonları, açığa çıkan dentinden dolayı hassasiyet ve buna bağlı fırçalama güçlüğü, artan plağın çocuklarda izlenen dişeti hastalıklarının en fazla görülen formu olan gingivitise zemin hazırlaması, gingivitise bağlı ödem ve yalancı cep oluşumudur. ${ }^{5}$

\section{Çocuklarda Periodonsiyumun Anatomisi}

Çocuklarda normal diş eti, serbest (marjinal) ve yapışık diş etinden oluşup, diş eti kenarı ve mukogingival bağlantı ile sınırlıdır. ${ }^{7}$ Yapışık diş eti, süt dişlerinde yuvarlak şekillidir. ${ }^{8}$ Dişler arası fizyolojik diastema durumunda papil eyer şeklindedir. ${ }^{7}$ Yapışık diş eti genişliği çocuklarda yetişkinlerden daha fazladır. ${ }^{7,9}$

Sulkus, yeni sürmüş bir dişteki yapışık diş etinin çok az miktarda içeri kıvrılması ve yuvarlanması ile oluşmaktadır. Yeni sürmüş bir dişte diş eti oluğu birkaç mm'dir ve dişin sürmesi sürecinde gittikçe azalmaktadır. ${ }^{7}$ Süt dişlerinin erüpsiyonuna eşlik eden lokalize kızarıkık kalııı olabilmekte ve şişmiş ve yuvarlaklaşmış interproksimal papillaya ve $3 \mathrm{~mm}$ 'yi aşan diş eti sulkusuna sebep olmaktadır. ${ }^{10,11}$ Süt dişlerinde en derin sulkus derinliği (SD) süt II. azı dişlerinde bulunmaktadır. ${ }^{12}$

Çocuklarda periodontal hastalığın tanısı için radyografi kullanıldığında erüptif değişiklikler dikkate alınmalıdır. Komşu dişlerin sürmesi veya düşmesi esnasında alveoler kemik kreti ve mine-sement bileşimi arasındaki mesafe bazı yüzeylerde $4 \mathrm{~mm}$ 'ye kadar çıkabilmektedir. Needleman ve arkadaşları, $^{13}$ bu mesafenin süt azı dişlerinde $0.58-1.39 \mathrm{~mm}$, daimi azı dişlerinde ise 0-0.63 mm olduğunu belirtmişlerdir.

Alveol kemiği, çocuklarda yetişkinlerle kıyaslandığında daha az trabeküler, daha büyük ilik boşluklu olup, damarlanma daha fazla ve daha az kalsifiyedir. Ligament daha az fibröz ve daha vaskülerdir. Lamina dura, sement ve kortikal tabaka daha ince, periodontal ligament boşluğu daha geniştir. Bütün bunlar süt dişlenme döneminde mevcut periodontal hastalığın gelişim oranını artırabilmektedir. ${ }^{9}$

\section{Hastalıkları}

Çocuklarda Görülen Diş Destek Dokusu

\section{a. Dişeti Hastalıkları}

Gingivitis, belirlenebilir bir klinik ataşman veya kemik kaybı olmaksızın diş eti enflamasyonu ile sonuçlanan ve çocuklarda yaygın olarak görülen bir hastalık olup, diş etini etkileyen bakteriyel ürünler nedeniyle oluşmaktadır. ${ }^{9010,14-16}$ Yapışık diş etinde biriken bakteriler ile konak savunma cevabı arasındaki dengenin konak aleyhinde bozulması ile ortaya çıkan lokal enfeksiyöz bir hastalıktır. ${ }^{17}$

Süt dişlenme döneminde, gingivitis yaklaşı 5 yaşında başlayıp, 10 yaşından önce daimi dişlerin sürmesi ile ilişkili olarak karışık dişlenme boyunca hızı bir artı̧̧ göstermektedir. ${ }^{8}$ Pubertede en yüksek değere ulaşmakta ve puberte sonrasında azalmaya başlamakta, fakat yaşam boyu nispeten yüksek kalmaktadır. ${ }^{9}$

Gingivitis tedavisinde ve önlenmesindeki en önemli unsur etkili oral hijyen ve plak kontrolünün sağlanmasıdır. Dişlerin fırçalanması, ara yüz temizliği, kimyasal plak kontrolü dental plağın uzaklaştırımasında önemlidir ve özellikle çocuklarda tam gelişmemiş kas tonusu nedeniyle elektrikli diş firçaları, geleneksel manuel diş fırçalarına bir alternatif sağlamaktadır. ${ }^{9-11,16}$

Pattanaporn ve Navia, ${ }^{18}$ çocuklarda diş taşı birikimi ile gingivitis ve plak arasında güçlü bir korelasyon olduğunu ve periodontal sağık açısından plak ve diş taşının önlenmesi gerektiğini belirtmişlerdir.

\section{b. Periodontal Hastalıklar}

Periodontitis, dişi çevreleyen destek dokuları içeren ve ilerleyen ataşman kaybı, kemik rezorpsiyonu ve/veya diş eti çekilmesi ile karakterize kronik enfeksiyoz bir hastalıktır. ${ }^{17,19}$ Diş yüzeyindeki bakteriyel birikimlere karşı oluşan kronik enflamatuar bir cevap olarak da bilinmektedir. ${ }^{10,11,14,16,20}$ TanıSI, SD ve ataşman

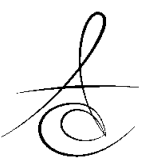


kaybı (AK)'nın periodontal sond ile değerlendirilmesi ve marjinal kemik kaybının radyografide belirlenmesi ile konulmaktadır.

Diabetes mellitus, nötropeni, AIDS gibi sistemik hastalıklar ve Papillon-Lefevre sendromu, EhlersDanlos sendromu gibi genetik hastalıklar; çocuk, ergen ve genç yetişkinlerde şiddetli periodontal yıkıma sebep olmaktadır. ${ }^{19}$ Bununla beraber ara yüz çürükleri, gıda sıkışması, uygun şekilde yerleştirilmemiş paslanmaz çelik kronlar (PÇK), kötü yapılmış restorasyonlar gibi lokal faktörlere bağlı olarak da, AK, alveoler kemik rezorpsiyonu ve/veya diş eti çekilmeleri görülebildiği belirtilmiştir. ${ }^{19,21}$ Ancak bu durum periodontitis değildir.

\section{Gıda sıkışması (Food impaction)}

Periodontal aralığa gıda sıkışması sonucu hastalarda; yemeklerden sonra basınç ve kürdanla kurcalama hissi, kötü bir tat ve koku, lokal diş eti iltihabı, lokal diş eti çekilmesi, pulpitis benzeri ağrı, periodontal apse, alveoler kemik kaybı, kök sement çürüğü ve perküsyonda ağrı görülmektedir. ${ }^{19,} 21$

Hancock ve arkadaşları, ${ }^{1}$ yapmış oldukları çalışmada, 104 ara yüz bölgesinin periodontal sağlıkla ilişkisini değerlendirmişler ve gıda sıkışmasının en çok ara yüz kontak kaybı olan dişlerde görüldüğünü, ara yüz kontağının gingival sağlık için gerekli olduğunu bildirmişlerdir.

\section{Çocuklarda Periodontal Muayene}

Periodontal dokuların sağlık durumunun değerlendirilmesinde genellikle aşağıdaki klinik parametreler kullanılmaktadır.

- Basitleştirilmiş oral hijyen indeksi (OHİ-S): Genel ağız içi plak durumunu değerlendirmek için kullanılmaktadır. ${ }^{22,23}$

- Plak indeksi (Pİ): Loe ve Silness, ${ }^{24}$ tarafından geliştirilmiştir. Dişin etrafındaki plak mevcudiyetini ve lokalizasyonunu tespit etmek için kullanılan bir indekstir.

- Gingival indeks (GI): Gingivitis varlığının ve şiddetinin tespitinde kullanılan bir indekstir. ${ }^{22,} 23$

- Sulkus derinliği (SD): Marjinal diş etinden diş aksı boyunca sondun ulaşabildiği en uzak noktaya kadar olan mesafenin mm cinsinden ölçümüdür. ${ }^{23}$

- Ataşman kaybı (AK): Mine-sement bileşiminden cep tabanına kadar olan mesafe olarak hesaplanmaktadır. ${ }^{25,26}$
- Diş eti oluğu sıvısı (DOS) hacmi: DOS'un transuda olduğu ve çeşitli uyaranlarla enflamatuar bir eksudaya dönüştüğü ileri sürülmektedir. ${ }^{27-29} \mathrm{Bu}$ SIVı miktarı enflamasyon durumunda artmaktadır. Çocuklardan DOS toplanması rahatlıkla uygulanabilir bir işlemdir.

Diş Çürüğü, Dental Restorasyonlar ve Oral Hijyenin Periodontal Parametrelerle İlişkisi

Dental restorasyonlar ve periodontal sağlık arasında yadsınamaz bir ilişki söz konusudur. Marginal adaptasyon, kontur, proksimal kontaklar ve yüzey özellikleri dişeti ve periodontal dokular üzerinde önemli biyolojik cevaplara neden olur. Marjinal kenarın gingival sulkusta lokalize olduğu dental restorasyonlarda, gingivada iltihabi cevap oluşma ihtimali yüksektir. ${ }^{30,31}$

Bazı dental restorasyon uygulamaları periodontal hastalığın oluşmasına davetiye çıkartmaktadır. Yaygın çürüklerin ve özellikle dişeti altına uzanan çürüklerin tedavisinde PÇK'lar yaygın olarak kullanılmaktadır. Ancak PÇK'ların periodontal sağlığı tehdit ettiği yönünde çalışmalar vardır. Berg ve arkadaşları, ${ }^{32}$ kronların adaptasyonu sırasında epitelyal ataşman ve serbest diş eti dokusunun mekanik olarak irrite olabileceği ve SD'nin artmasına katkıda bulunabileceğini belirtmişlerdir.

Kara, ${ }^{33}$ PÇK uygulanmış dişlerde DOS miktarını 18 aya kadar takip etmiş ve ortalama DOS miktarının zamana bağlı olarak kademeli arttığını bildirmiştir. Tedaviden sonra artmasını, diş etinde oluşan enflamasyona ve sulkustaki iritasyona bağlarken, zamana bağlı DOS artışını Pİ'nin artması ve buna bağlı GI'nin artması ile ilişkilendirmiştir. PÇK'ı dişlerde takip süresi boyunca hafif gingivitise rastlanıldığı ifade edilmiştir.

Kayalıbay, ${ }^{34}$ PÇK'li dişler ile restorasyonsuz dişlerin SD ölçüm değerleri arasında istatistiksel açıdan anlamlı bir fark olmadığını, bununla birlikte PÇK'lı dişlerin bir miktar daha yüksek değerler sergilediğini rapor etmiştir.

Diş eti altında konturlanmış ve iyi bir cilalama yapılmış kompozit rezinlerin gingival sağlığı olumsuz yönde etkilemediği bildirilmiştir. ${ }^{35}$ Kompomerlerin süt azılarda sınıf II kavitelerde kullanımlarını değerlendiren çok sayıda klinik çalışma yapılmış ve bu restorasyonlar klinik olarak yüksek başarı oranı sergilemiştir. ${ }^{36-38}$

Çocuklar üzerinde yapılmış çalışmalarda OHİ-S skorunda kaydedilen olumlu değişimin ağız içerisindeki 
tüm çürüklü dişlerin restore edilmesine bağlı olarak dişlerin orijinal formlarını kazanması sonucu gıda akışının sebep olduğu fizyolojik temizlenmenin geri sağlanmasıyla ve çocuklara ve ebeveynlere oral hijyen eğitimi verilmesiyle ilgili olduğu bildirmiştir. 39,33,40,41

Çürük kaynaklı oluşan kaviteler plak birikimi için ciddi bir retansiyon yeri oluşturduğundan bu dişlerin restorasyonu sonrası bu dişlerde plak tutulumu başlangıca göre oldukça azalmakta ve klinik ve laboratuvar parametreler sağlıklı dişlere yakın değerler sergilemektedir. Bu durumun plak birikimi için retansiyon yeri olan kavitelerin kapatılması, gıda birikimi ve bu gıdaların periodonsiyuma sıkışması sonucu ortaya çıkan ağrı şikayetiyle kullanılamayan dişlerin restorasyon sonrası kullanımına bağlı olarak çiğnemenin katkısıyla mekanik temizliğin geri kazanılması ve süt dişlerinde florür salan ve bu salınan florür ile bakterilerin pelikıla tutunmasına engel olan restoratif materyallerle (örneğin kompomer) ${ }^{39}$ restore edilmesi ve bu restorasyonların iyi cila yüzeyine sahip olmasından kaynaklandığı bildirmiştir. ${ }^{41}$

Pİ ve Gİ arasındaki korelasyonla ilgili farklı görüşler vardır. Mackler ve arkadaşları ${ }^{42}$ ile Bimstein ve arkadaşları, $^{43}$ süt dişlenmesinde plak miktarı ve gingivitis arasında bağlantı olmadığını vurgularken, Loe, ${ }^{27}$ plak mevcudiyetinin gingivitis için ön şart olduğunu bildirmiştir.

Diş etlerinde kanamaya eğilimin artmasının, gingival enflamasyonun en erken belirtilerinden biri olduğu bilinmektedir. ${ }^{29}$ Restorasyonlu dişlerde Gİ nin restorasyonsuz dişlere göre yüksek olduğunu bildiren çalışmalar gerekçe olarak en ideal dolgu materyalinin bile biyolojik ortama yabancı olup, bu ortamı etkileyen çeşitli kimyasal maddeler içerdiğini savunmaktadırlar. ${ }^{44,45}$

\section{Sulkus Derinliği ve Ataşman Kaybının Periodontal Sağlıkla İlişkisi}

Süt dişlerinde SD'nin artışı, derin ara yüz çürükleri, kötü yapılmış restorasyonlar ve PÇK uygulamaları sonucu marjinal diş etindeki enflamatuar değişikliklerden dolayı, ya yalancı cep oluşumu ya da sulkus tabanındaki destek yapıların apikale yer değiştirmesi ile açıklanmaktadır. ${ }^{46}$ Ara yüz çürüklü dişlerde gıda sıkışmasına bağlı oluşan lokal irritasyonun sulkus tabanını apikale doğru itmesinden kaynaklı artan SD dişlerin restore edilmesiyle geri kazanılan kontak so- nucu irritasyonun ortadan kalkmasıyla tekrar fizyolojik sınırlara yaklaşacaktır.

Araştırmacılar, AK ve bağlantı epitelinin minesement bileşiminden apikale yer değiştirmesi olmasa bile, derin cepler ile karşılaşılabileceğini bildirmişlerdir. ${ }^{47} \mathrm{Bu}$ durum doku yıkımının çok az olması veya periodontal bağ doku yıkımı olmadan diş eti kenarının kuronal yönde büyümesiyle (yalancı cep) açıklanabilir. ${ }^{48}$ Gingivitise bağlı oluşan ödemin sebep olduğu yalancı cep etkenin ortadan kaldırılmasıyla yok olacaktır.

Çekilmiş ara yüz çürüklü 200 süt azı dişi üzerinde yapılmış bir çalışmada, bu dişlerin \%47'sinde AK $>0.5 \mathrm{~mm}$ olarak tespit edilirken, \% 6.3'ünde AK>1 mm tespit edilmiştir. ${ }^{49} A K^{\prime} n ı n$ daha çok ara yüz çürüğü ve kötü yapılmış ara yüz dolgusu olan dişlerde diş taşı birikimi sonucu görüldüğü, ayrıca marjinal kemik kaybının en fazla süt I. azılarda olduğu rapor edilmiştir. ${ }^{50,51}$

Araştırmacılar AK'nın SD ile doğru orantılı olduğunu bildirmişlerdir. ${ }^{52,53} \mathrm{Bu}$ da plağa bağlı gingivitisin SD ve $A K^{\prime} y ı$ tetiklediğinin bir göstergesidir. ${ }^{54}$

\section{DOS Hacmi ve Periodontal Sağlık Arasındaki İlişki}

DOS, diş etindeki enflamasyonun erken tanısının konulması ve böylece hastalık ilerlemeden erken tedavisine başlanılmasında önemlidir. ${ }^{20}$ Emici kağıt şeritler ile DOS toplanmasının avantajı, hızlı ve kulanımının kolay olmasıdır. Her bölgeye uygulanabilmekte ve doğru kullanıldığında en az travmatik yöntem olarak bilinmektedir. ${ }^{29} \mathrm{Bu}$ avantajlarından dolayı bu yöntem, çocuklarda rahatlıkla uygulanabilir. DOS, önceleri emici kağıt şeritlerin doğrudan incelenmesi veya ninhidrin veya fluorescein ile boyanarak değerlendirilmesi ve emici kağıt şeritlerin tartılması şeklindeydi. Son yıllarda ise, periotron cihazı ile değerlendirilmektedir. ${ }^{55-57}$

Periotron; DOS ve tükürük akışı ve yoğunluğunun ölçülebilmesine imkan veren çeşitli emici kağıt şeritlerin kullanılmasına izin verecek şekilde dizayn edilmiş mikro nem ölçen elektronik bir alettir. ${ }^{29}$

Toplanan DOS hacminin süt II. azı dişlerinde süt I. azı dişlerine ve süt kaninlere göre daha yüksek olduğu bildirimiştir. ${ }^{33,41} \mathrm{Bu}$ durum daha derin SD'ye sahip dişlerde emici kağıt şeritlerin oluk içindeki temas alanının artmasıyla açıklanmıştır. 
Sandallı, ${ }^{58}$ sağlıklı çocukların restorasyonsuz süt dişlerinde gingivitis varlığında DOS hacminin arttığını bildirmiştir. Smith ve arkadaşları, ${ }^{59}$ benzer şekilde çocukların restorasyonsuz dişlerinde Gínin artmasıyla DOS hacminin arttığını bildirmiştir.

Checcio ve arkadaşları, ${ }^{60} 7-11$ yaşları arasındaki çocuklara yerleştirmiş oldukları PÇK'ların Gİ skoru O'dan 2'ye arttıkça DOS hacminin de arttığını ifade etmişlerdir. Van Dijken ve arkadaşları, ${ }^{39}$ yaptıkları çaış̧mada DOS hacmini, rezin esaslı restorasyonlu dişlerde, restorasyonsuz dişlerden daha yüksek bulmuşlardır.

Griffiths ve arkadaşları, $^{29}$ diş etlerinde kanamaya eğilimin artmasının, diş etindeki enflamasyonun en erken belirtilerinden biri olduğunu ve buna bağlı olarak bu bölgelerde DOS üretimi olduğunu vurgulamışlardır.

Van Dijken ve arkadaşları, ${ }^{39,61}$ dolgu materyalleri üzerine yapmış oldukları iki farklı çalışmada, doldurucu içerikli restoratif materyallerin etrafında mikroorganizmaların daha fazla kolonize olması sonucu daha fazla plak birikimi oluşabileceği ve buna bağı olarak DOS hacmini artırabileceğini bildirmişlerdir.

Sandallı, ${ }^{58}$ 3-5 yaş arası çocuklarda sağlıklı diş etinde SD ile DOS hacmi arasında zayıf bir pozitif ilişki olduğunu, gingivitis geliştikçe bu ilişkinin güçlendiğini belirtmiştir. Preiss ve arkadaşları, ${ }^{62}$ 3-13 yaşları arasındaki çocukların restorasyonsuz tüm dişlenme dönemlerinde SD ile DOS hacmi arasında güçlü bir pozitif ilişki bulmuşlardır.

DOS hacmi, ara yüz çürüklü süt II. azılarda sağlıklı dişlere kıyasla yüksek bulunmuştur. ${ }^{41}$

\section{Çürüklü ve Restorasyonlu Dişler ile Enflamasyon Markerleri Arasındaki İlişki}

Yapılan çalışmalarda bonding ajanların ve çocuklarda yaygın olarak kullanılan kompomer restorasyonların kimyasal bileşimine karşı gingival cevabın periodontal dokuların zarar görmesi şeklinde olduğu rapor edilmiştir. ${ }^{44,45}$ Bu materyaller değişik boyutlarda hücresel toksisiteye sebep olmaktadır. ${ }^{63,64}$ Düşük miktarlarda salımları (HEMA, TEGDMA, UDMA v.b.) hücresel cevapta herhangi bir değişikliğe sebep olmasa da, enflamatuar cevap için risk teşkil edebilmektedir. ${ }^{45}$ aynı şekilde çürüğe bağı periodontal harabiyet sonucu da enflamatuar cevap oluşabilmektedir.

Periodonsiyumdaki hücresel enflamatuar cevabl, proenflamatuar sitokinler (IL-1a, IL-1 $\beta$, TNF-a, IL-
6) tarafından yürütülürken, antienflamatuar sitokinler (IL-1Ra, IL-4, -10) bu süreci kontrol etmeye çalışılar. ${ }^{65,66}$ Enfeksiyoz bir hastalık olan periodontal doku yıkımında proenflamatuar sitokinlerin sorumlu olduğu ve bu sitokin düzeylerinin tükürük ve DOS'da arttığı bildirilmektedir. ${ }^{67}$

Çürüğe bağlı sırt sırta kavitasyonların olduğu süt azılarda gıda sıkışması sonucu periodontal harabiyetin tespit edildiği ve bu bölgede DOS'ta proenflamatuar sitokin seviyelerinde artı̧̧ olduğu rapor edilmiştir. $^{41}$

Sonuç olarak dişeti bölgesine kadar uzanan çürüklü dişler periodontitisli dişler gibi değerlendirilip kaybolan kontağın veya servikal sırtın geri kazanılması için dişlerin tedavisi en kısa sürede yapılmalıdır. Aksi takdirde enflamasyon gelişmekte ve artan enflamasyon markerleri doku hasarını artmasına katkıda bulunarak olayın kompleksleşmesine yol açmaktadır.

DOS'ta periodontal hastalık markerleri ile ilgili erişkinlerde çok sayıda çalışma mevcuttur. Ancak çocuklarda periodontal harabiyetli dişlerde DOS parametrelerindeki değişimle ilgili çalışmalar yetersiz olup, ${ }^{41,54}$ yapılmış çalışmalar da daha çok klinik parametreler üzerinedir ${ }^{33,50,51}$ Bu sebepten periodontal hastalıkların patogenezinin anlaşılabilmesi ve yeni terapötik metotların geliştirilebilmesi için periodontal hastalık markerlerinin çocuklarda araştııılığı daha fazla çalışmaya intiyaç duyulmaktadır.

Gülsüm Duruk: $O R C I D I D: 0000-0002-6756-6637$

Taşkın Gürbüz: ORCID ID: 0000-0002-8911-6530

\section{KAYNAKLAR}

1. Hancock EB, Mayo CV, Schwab RR, Wirthlin MR. Influence of interdental contacts on periodontal status. J Periodontol 1980; 51: 445-9.

2. Allukian M. The neglected epidemic and the surgeon general's report: a call to action for better oral health. Am J Public Health, 2000; 90: 843-5.

3. Manisalı $Y$, Koray F. Ağız diş embriyolojisi ve histolojisi. İstanbul; Yenilik Basımevi: 1982. p. 99106.

4. Murray JJ, Majid ZA. The prevalence and progression of approximal caries in the deciduous dentition in British children. Br Dent J, 1978; 145: 161-4.

5. Arnold WH, Gaengler P, Kalkutschke L. Threedimensional reconstruction of approximal

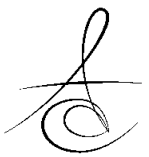


subsurface caries lesions in deciduous molars. Clin Oral Investig, 1998; 2: 174-90.

6. Poggio C, Chiesa M, Dagna A, Colombo M, Scribante $A$. Microleakage in class $V$ gingivashaded composite resin restorations. Ann Stomatol (Roma), 2012; 3: 19-23.

7. Bimstein $\mathrm{E}$. The normal gingiva and periodontium. In:Needleman $\mathrm{HL}$, Karimbux $\mathrm{N}$, Van Dyke TE (eds.). Periodontal and gingival health and diseases, Martin Dunitz Ltd: 2001. p.19-27.

8. Caranza FA. Glikman's clinical periodontology. 7th ed. Philadelphia; WB Saunders Company: 1990. 286-292, p.302-29.

9. Carranza FA. Gingival diseases in childhood. In:Newman MG, Takei HH, Carranza FA (eds.). Clinical Periodontology. 9th ed. Philadelphia; W.B. Saunders Company: 2002. p. 308-13.

10. Matsson L. Periodontal conditions in children and adolescents. In:Koch G, Poulsen S (eds.). Pediatric Dentistry. 1st ed. Copenhagen: Wiley-Blackwell; 2001. 235-52.

11. Heasman PA, Waterhouse PJ. Periodontal diseases in children. In:Welbury RR, Duggal MS, Hosey MT (eds.). Pediatric Dentistry. 3rd ed. Oxford; Oxford University Press: 2005. p. 231-56.

12. Kırzıoğlu Z, Karatoprak O. Karışık dişlenme boyunca gingival sulkus ve bağlı gingivada boyutsal farklılıklar. Atatürk Üniv Diş Hek Fak Derg 1994; 4: 67-72.

13. Needleman HL, Ku TC, Nelson L, Allred E, Seow WK. Alveolar bone height of primary and first permanent molars in healthy seven- to nine-yearold children. ASDC J Dent Child 1997; 64: 188-96, 165.

14. Macphee T, Cowley G. Classification of periodontal disease. In:MacPhee IT, Cowley GC (eds.). Essentials of Periodontology and Periodontics. 3rd ed. Oxford; Willey-Blackwell: 1981. 127-34.

15. Pilot T, Barmes DE, Leclercq MH, McCombie BJ, Sardo Infirri J. Periodontal conditions in adolescents, 15-19 years of age: an overview of CPITN data in the WHO Global Oral Data Bank. Community Dent Oral Epidemiol, 1987; 15: 336-8.

16. Califano JV. Periodontal diseases of children and adolescents. Pediatr Dent, 2005; 27: 189-96.
17. Kinane DF. Causation and pathogenesis of periodontal disease. Periodontol 2000 2001; 25: 820.

18. Pattanaporn K, Navia JM. The relationship of dental calculus to caries, gingivitis, and selected salivary factors in 11- to 13-year-old children in Chiang Mai, Thailand. J Periodontol 1998; 69: 95561.

19. Page RC, Sims TJ, Delima AJ, Bimstein E, Needleman HL, Van Dyke TE. The relationship between periodontitis and systemic diseases and conditions in children, adolescents and young adults. In:Bimstein $\mathrm{E}$, Needleman $\mathrm{HL}$, Karimbux $\mathrm{N}$, Van Dyke TE (eds.). Periodontal and Gingival Health and Diseases. 1st ed. UK; Martin Dunitz Ltd.: 2001.p. 107-143.

20. Champagne CM, Buchanan W, Reddy MS, Preisser JS, Beck JD, Offenbacher S. Potential for gingival crevice fluid measures as predictors of risk for periodontal diseases. Periodontol 2000 2003; 31: 167-80.

21. Bimstein E, Delaney JE, Sweeney EA. Radiographic assessment of the alveolar bone in children and adolescents. Pediatr Dent 1988; 10: 199-204.

22. Harris NO, Willmann DE. Periodontal disease prevention: risk assesment and evaluation. In:Harris NO, Garcia-Godoy F (eds.). Primary Preventive Dentistry. 5th ed. Stamford; Connecticut, A Appleton \& Lange Company: 1999. 327-51.

23. Rateitschak KH, Wolf HF. Dişhekimliğinin Renkli Atlası 1. 1. Baskı. Ankara; Palme Yayıncılık: 2007. p. 67-73, 155-64.

24. Silness J, Löe H. Periodontal disease in pregnancy. II. Correlation between oral hygiene and periodontal condition. Acta Odontol Scand, 1964, 22: 121-35.

25. Carranza FA. Clinical diagnosis. In:Newman MG, Takei HH, Carranza FA (eds.). Clinical Periodontology, 9th ed. Philadelphia; W.B. Saunders Company: 2002: 432-53.

26. Armitage GC. Diagnosis of periodontal diseases. J Periodontol 2003, 74: 1237-47.

27. Loe H, Holm-Pedersen P. Absence And Presence Of Fluid From Normal And Inflamed Gingivae. Periodontics 1965; 149: 171-7.

28. Alfano MC. The origin of gingival fluid. J Theor Biol 1974; 47: 127-36. 
29. Griffiths GS. Formation, collection and significance of gingival crevice fluid. Periodontol 2000 2003; 31: 32-42.

30. Develioglu $H$, Kesim B, Tuncel A. Evaluation of the marginal gingival health using laser Doppler flowmetry. Braz Dent J, 2006; 17: 219-22.

31. Newcomb GM. The relationship between the location of subgingival crown margins and gingival inflammation. J Periodontol, 1974; 45: 151-4.

32. Berg J, Pettey D, Hutchins M. Microleakage of three luting agents used with stainless steel crowns. Pediatr Dent, 1988; 10: 195-8.

33. Kara N. Geleneksel Paslanmaz Çelik Kronların ve Farklı Şekillerde Estetik Hale Getirilmiş Kronların Klinik ve Radyografik Başarılarının ve Gingival Dokularda Meydana Getirdikleri Değişikliklerin Değerlendirilmesi. Sağlık Bilimleri Enstitüsü, Pedodonti Anabilim Dalı. Doktora tezi, Erzurum: Atatürk Üniversitesi, 2008.

34. Kayalıbay $H$. Paslanmaz çelik kuron uygulanan çocuklarda, ağız hijyeni, gingivitis ve cep derinliklerinin incelenmesi. Hacettepe Diş Hek Fak Derg 1990; 14: 123-7.

35. Blank LW, Caffesse RG, Charbeneau GT. The gingival response to well-finished composite resin restorations: a 28-month report. J Prosthet Dent 1981; 46: 157-60.

36. Duggal MS, Toumba KJ, Sharma NK. Clinical performance of a compomer and amalgam for the interproximal restoration of primary molars: a 24month evaluation. Br Dent J, 2002; 193: 339-42.

37. Gross LC, Griffen Al, Casamassimo PS. Compomers as class II restorations in primary molars. Pediatr Dent 2001; 23: 24-7.

38. Mass $E$, Gordon M, Fuks AB. Assessment of compomer proximal restorations in primary molars: a retrospective study in children. ASDC J Dent Child 1999, 66: 93-7, 84.

39. van Dijken JW, Sjostrom S. The effect of glass ionomer cement and composite resin fillings on marginal gingiva. J Clin Periodontol, 1991; 18: 200-3.

40. Eyüboğlu Ö. Farklı Materyaller Kullanılarak Yapılan Süt Dişi Amputasyonlarının Klinik, Radyografik ve Histolojik Olarak Değerlendirilmesi. Sağlık Bilimleri Enstitüsü, Pedodonti Anabilim Dalı. Doktora tezi, Erzurum: Atatürk Üniversitesi, 2007.
41. Duruk G. Çocuklarda Ara Yüz Çürüklerinin Biyokimyasal DOS Parametreleri ve Klinik Ölçümler Üzerine Etkisi. Sağlık Bilimleri Enstitüsü, Pedodonti Anabilim Dalı. Doktora tezi, Erzurum: Atatürk Üniversitesi, 2013.

42. Mackler SB, Crawford JJ. Plaque development and gingivitis in the primary dentition. J Periodontol, 1973; 44: 18-24.

43. Bimstein E, Lustmann J, Soskolne WA. A Clinical and Histometric Study of Gingivitis Associated with the Human Deciduous Dentition. J Periodontol 1985; 56: 293-6.

44. Redlich M, Harary D, Shoshan S. Gingival response to a new multipurpose dental adhesive: a histologic study in dogs. J Prosthet Dent, 1996; 76: 379-85.

45. Noda M, Wataha JC, Lockwood PE, Volkmann KR, Kaga M, Sano H. Sublethal, 2-week exposures of dental material components alter TNF-alpha secretion of THP-1 monocytes. Dent Mater 2003; 19: 101-5.

46. Delima AJ, Sjödin BE, Tonetti MS, Bimstein E, Newman HN, Van Dyke TE. Periodontal diseases in children, adolescents, and young adults. In:Bimstein $\mathrm{E}$, Needleman $\mathrm{HL}$, Karimbux $\mathrm{N}$, Van Dyke TE (eds.). Periodontal and Gingival Health and Diseases, 11th ed. UK; Martin Dunitz Ltd: 2001. p. 75-105

47. Ellwood R, Worthington HV, Cullinan MP, Hamlet S, Clerehugh V, Davies R. Prevalence of suspected periodontal pathogens identified using ELISA in adolescents of differing ethnic origins. J Clin Periodontol 1997; 24: 141-5.

48. Clerehugh V, Tugnait A. Diagnosis and management of periodontal diseases in children and adolescents. Periodontol 2000 2001; 26: 14668.

49. Keszthelyi G, Szabo I. Attachment loss in primary molars. J Clin Periodontol, 1987; 14: 48-51.

50. Aass AM, Tollefsen T, Gjermo P. A cohort study of radiographic alveolar bone loss during adolescence. J Clin Periodontol 1994; 21: 133-8.

51. Albandar JM, Brown L, Loe H. Dental caries and tooth loss in adolescents with early-onset periodontitis. J Periodontol 1996; 67: 960-7. 
52. Kadkhoda Z, Tari SR, Owlia P, Sabounchei SSZ. Comparison of 1-periodontal indices and cultural porphyromonas gingivalis colony count in aggressive periodontitis patients treated by scaling and rootplanning with or without metronidazole gel. J Dent (Tehran), 2012; 9: 50-8.

53. Cobb CM. Non surgical pocket therapy: mechanical. Ann of Periodontol, 1996; 1: 443-90.

54. Ülker E. Sağlıklı ve Periodontal Hastalığı Olan Çocuklarda Tükrükte ve Dişeti Oluğu Sıvısında Sistatin C, İnterlökin-1beta ve Tümör Nekrozis Faktör-alfa Düzeylerinin Değerlendirilmesi. Sağlık Bilimleri Enstitüsü, Pedodonti Anabilim Dalı. Doktora tezi, Ankara: Gazi Üniversitesi 2007.

55. Cimasoni G. Crevicular fluid updated. Monogr Oral Sci 1983; 12: 1-152.

56. Sandallı P. Periodontoloji. İstanbul; Erler Matbaası: 1981. p. 8-24.

57. Ciantar M, Caruana DJ. Periotron 8000: calibration characteristics and reliability. J Periodontal Res 1998; 33: 259-64.

58. Sandalli $P$, Wade AB. Crevicular fluid flow in young children. J Periodontol, 1971, 42: 713-6.

59. Smith LB, Golub LB, Duperon DF. An evaluation of crevicular fluid and gingival tissue in children. ASDC J Dent Child, 1974; 41: 128-32.

60. Checchio LM, Gaskill W, Carrel R. The relationship between periodontal disease and stainless steel crowns. J Dent Child, 1983; 50: 205-9.

61. van Dijken JW, Sjostrom S, Wing K. The effect of different types of composite resin fillings on marginal gingiva. J Clin Periodontol 1987; 14: 1859.

62. Preiss DS, Meyle J. Interleukin-1 beta concentration of gingival crevicular fluid. J Periodontol 1994; 65: 423-8.

63. Bowen RL. Compatibility of various materials with oral tissues. I: the components in composite restorations J Dent Res 1979; 58: 1493-503.

64. Stanley HR, Bowen RL, Folio J. Compatibility of various materials with oral tissues. II: pulp responses to composite ingredients J Dent Res 1979; 58: 1507-17.

65. Gemmell E, Seymour GJ. Cytokine profiles of cells extracted from humans with periodontal diseases. J Dent Res 1988; 77: 16-26.
66. Suryono, Kido J, Hayashi N, Kataoka M, Nagata T. Effect of Porphyromonas gingivalis lipopolysaccharide, tumor necrosis factor-alpha, and interleukin-1beta on calprotectin release in human monocytes. Journal of Periodontology, 2003; 74: 1719-24.

67. Kido J, Hayashi N, Kataoka M, Nagata T. Calprotectin expression in human monocytes: induction by porphyromonas gingivalis lipopolysaccharide, tumor necrosis factor-alpha, and interleukin-1beta. Journal of Periodontology 2005; 76: 437-42.

\author{
Yazışma Adresi \\ Dr. Gülsüm Duruk \\ İnönü Üniversitesi \\ Diş Hekimliği Fakültesi \\ Pedodonti Anabilim Dalı \\ Malatya \\ Tel: 05367790404 \\ e-posta: durukgulsum@yahoo.com
}

